\title{
The distribution of sulphur in the soils and herbage of North West Pembrokeshire
}

\author{
By CAROLYN WILLIAMS \\ Rothamsted Experimental Station, Harpenden, Herts
}

(Received 30 September 1974)

\begin{abstract}
SUMMARY
In North West Pembrokeshire, sulphur was determined in soils sampled at 268 sites, and in pasture plants sampled at 172 sites. The sulphur contents of the topsoils ranged from 199 to $3392 \mathrm{mg} / \mathrm{kg}$, with a mean of $710 \mathrm{mg} / \mathrm{kg}$; and the $\mathrm{S}$ contents of the subsoils from 115 to $1344 \mathrm{mg} / \mathrm{kg}$, with a mean of $356 \mathrm{mg} / \mathrm{kg}$. Sulphur was concentrated in soils containing much organic matter. There was no clear relationship between plant and soil sulphur contents, though soil drainage influenced both. Poorly drained soils were richer in $\mathrm{S}$ than well-drained soils, whereas herbage on poorly drained soils accumulated less $\mathrm{S}$ than herbage growing on well-drained soils. Herbage $\mathrm{S}$ contents ranged from 0.180 to $0.560 \%$, with a mean of $0.310 \%$. If other factors, e.g. soil $\mathrm{N}$, are not limiting, $14 \%$ of the herbage sampled in Pembrokeshire had less than the critical $\mathrm{S}$ level recommended by other workers for maximum dry matter yield.
\end{abstract}

\section{INTRODUCTION}

Sulphur is an essential element for plant growth. In the past much of the $S$ needed for plant nutrition has been supplied by the atmosphere, into which $\mathrm{S}$ is released during fuel combustion, and by fertilizers, many of which contained $\mathrm{S}$ as an impurity. As purer fertilizers are used, and atmospheric pollution is controlled, less $S$ is derived from these sources, and it is expected that $S$ deficiencies in ugricultural areas will become more widespread (Sulphur Institute, 1962) although, at present, only $\mathfrak{a}$ few cases of $\mathrm{S}$ deficiency have been reported in England (Bolton \& Benzian, 1970; Cowling \& Jones, 1970).

The present investigation is part of a larger project to investigate, primarily, the use of grid sampling as an aid to soil mapping and land classification (Rudeforth \& Bradley, 1972), and relationships between various trace elements and rock and environmental factors. The same samples have been used to study the distribution of $S$ in the soils and herbage of North West Pembrokeshire, to study the relationship between soil $S$ and $S$ in herbage grown in field conditions, and the dependence of this relationship on other soil factors. The region is mainly agricultural and attention may be drawn to actual and potential S deficiency in the pasture plants of this area.

\section{EXPERIMENTAL PROCEDURE}

Pits were dug throughout Pembrokeshire at the $1 \mathrm{~km}$ intersections of the Ordnance Survey grid. Surface soil and subsoil samples were taken at depths of 10 and $50 \mathrm{~cm}$ respectively, bulked from soil within $\pm \mathbf{5} \mathrm{cm}$ of these depths. Where bedrock was shallower than $50 \mathrm{~cm}$, the depth was noted and the sample taken just above bedrock. Field observations were made at each site. For the study of the distribution of $\mathrm{S}$, samples were taken from alternate sites to make a $\sqrt{ } 2 \mathrm{~km}$ grid diagonal to the O.S. grid of the area shown in Fig. $1(a)$. Grab samples of herbage from pasture were also taken at these points in the smaller area shown in Fig. 1 (a). The herbage samples were collected in May and June, and consisted, when possible, of grass only, or if the pasture were mixed, of grass and clover; two small areas were chosen for a more intensive study in which separate samples of grass, clover and mixed vegetation were collected monthly from March to September. The samples were harvested $2 \mathrm{~cm}$ above ground level to minimize soil contamination.

Soil samples were prepared for analysis by airdrying, and the $<2 \mathrm{~mm}$ fraction was ground for $10 \mathrm{~min}$ in a tungsten carbide disk mill. The $\mathrm{S}$ contents of soils and herbage were determined by $\mathrm{X}$-ray fluorescence spectrography (XRFS) (Bolton 


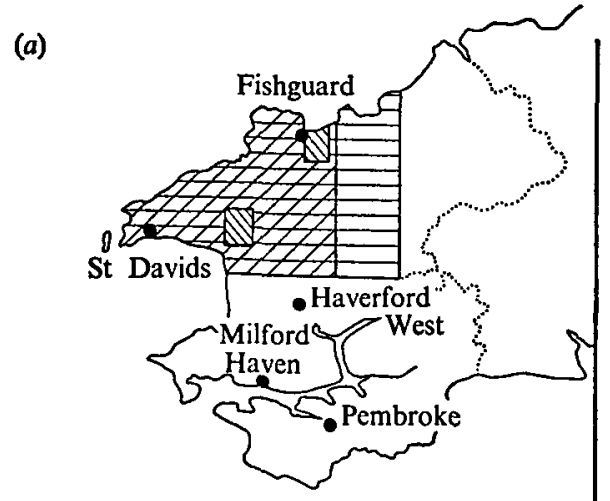

(d)

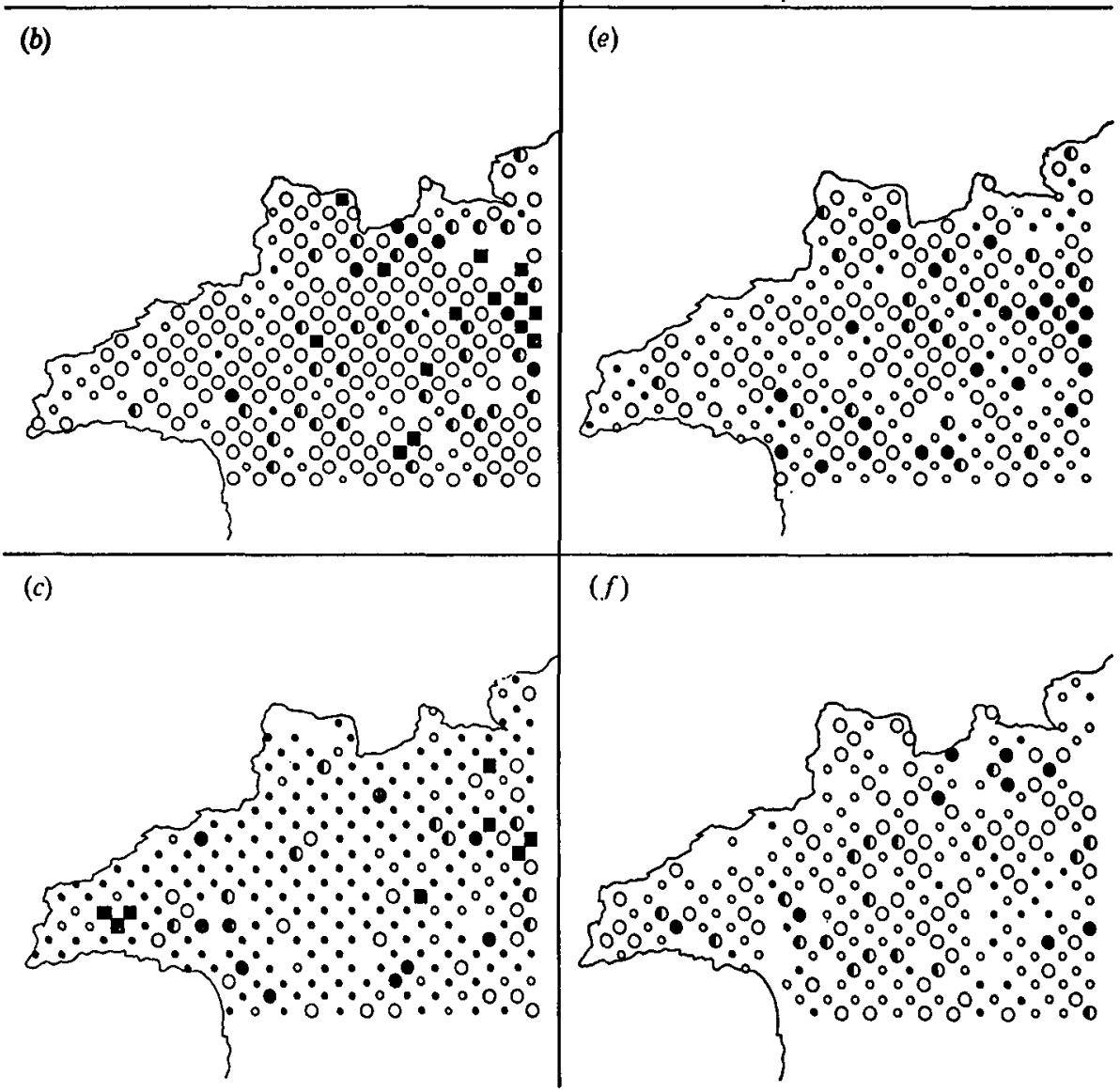

Fig. 1. (a) Sampled areas of soil $($ 目), monthly herbage samples $(\mathbb{\$})$ and main herbage samples $(\square)$. (b) Loss on ignition in topsoil, $\bullet,\langle 3 ; 0,3-5.9 ; 0,6-9 \cdot 9 ; 0,10-13 \cdot 9 ; \bullet, 14-19 \cdot 9 ; \square, \geqslant 20 \%$. (c) Soil drainage class, $\bullet, 1$ (well drained); 0,$2 ; 0,3 ; 0,4 ; 0,5 ; \mathbf{C}, 6$ and 7 (poorly drained).(d) Sulphur in herbage, $\bullet,<0.220 ; 0,0.220-0.279 ; 0,0.280-0.339 ; 0 ; 0.340-0.399 ; \bullet, 0.400-0.449 ; \square$, $\geqslant 0.450 \%$. (e) Sulphur in topsoil, $\bullet,<400 ; 0,400-599 ; 0,600-799 ; 0,800-999 ; \bullet, \geqslant 1000 \mathrm{mg}$ S/kg. $(f)$ Sulphur in subsoil, $\bullet,<200 ; 0,200-349 ; 0,350-499 ; 0,500-699 ; \bullet, \geqslant 700 \mathrm{mg} \mathrm{S} / \mathrm{kg}$. 


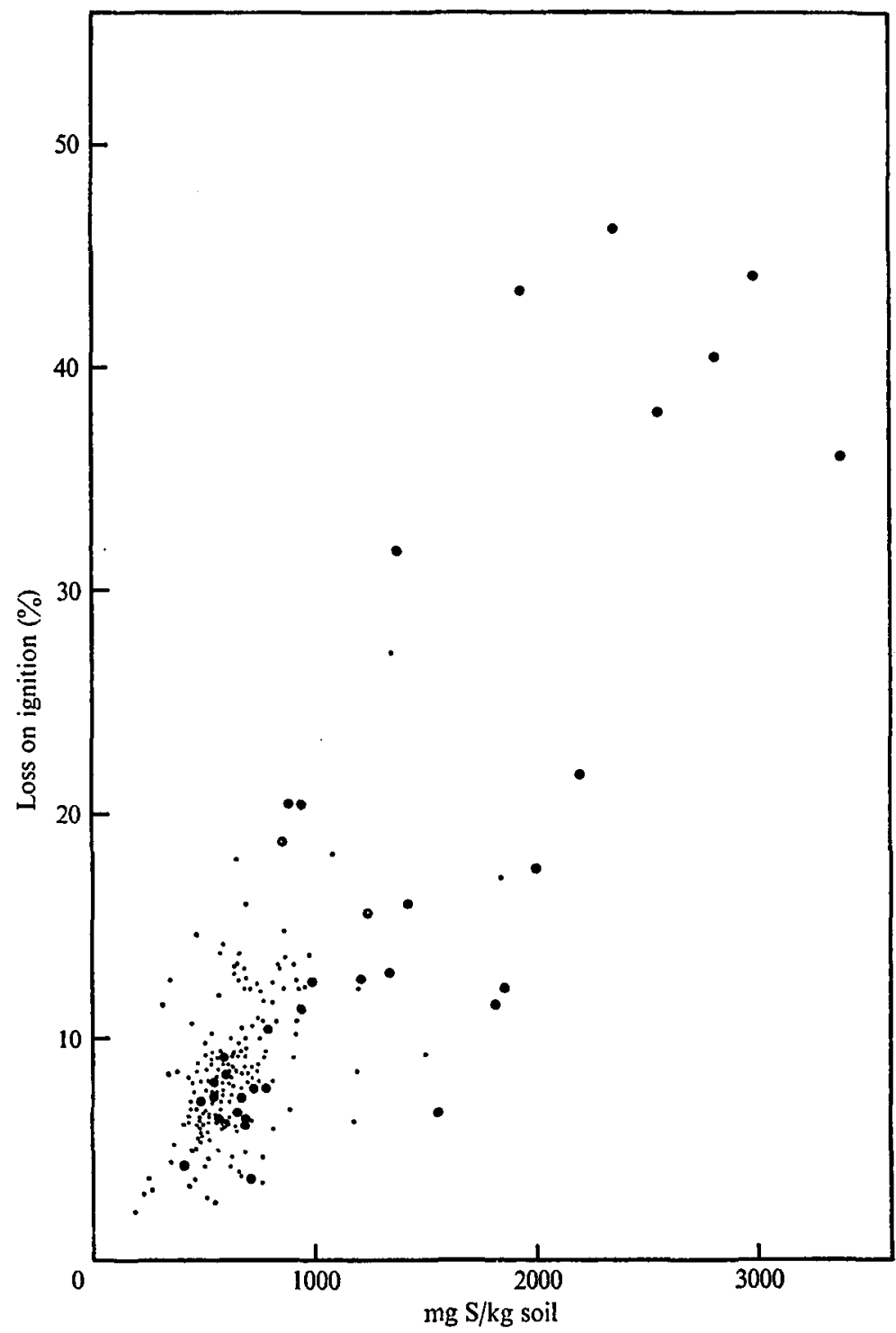

Fig. 2. The relationship between soil sulphur content, soil drainage and soil loss on ignition.

(Soils sampled at $10 \pm 5 \mathrm{~cm}$.) $\bullet$, Soil drainage class 1,$2 ; 0$, soil drainage class 3-7.

et al. 1973; Brown \& Kanaris-Sotiriou, 1969). As a rough measure of soil contamination the Ti contents of the herbage were determined semi-quantitatively by XRFS (Williams, 1974). As an estimate of the organic matter content of the soils, losses on ignition were determined by the method of Ball (1964).

\section{RESULTS}

Maps showing the distribution of $\mathrm{S}$, loss on ignition and soil drainage in North West Pembrokeshire are presented in Fig. 1 . The $\mathrm{S}$ contents of the topsoils ranged from 199 to $3392 \mathrm{mg} / \mathrm{kg}$, with a mean of $710 \mathrm{mg} / \mathrm{kg}$, excluding one soil with $86 \%$ loss on ignition and approximately $1 \% \mathrm{~S}$. In the subsoil samples the sulphur contents ranged from 115 to $1344 \mathrm{mg} / \mathrm{kg}$, with a mean of $356 \mathrm{mg} / \mathrm{kg}$. The $\mathrm{S}$ is concentrated in soils with very high organic matter content and poor drainage (Figs. 1, 2); within a profile, it is concentrated in the topsoil. Only $9 \%$ of the subsoil samples had $S$ contents greater than those of the topsoils of the same profile.

There does not seem to be a clear-cut distribution 
Table 1. Variation of soil S content with geology

\begin{tabular}{|c|c|c|c|c|c|c|c|}
\hline & & Rhyolite & Dolerite & $\begin{array}{c}\text { Lower } \\
\text { Palaeozoic } \\
\text { sediments }\end{array}$ & $\begin{array}{c}\text { Carboniferous } \\
\text { shale }\end{array}$ & $\begin{array}{l}\text { Millstone } \\
\text { grit }\end{array}$ & Keratophyre \\
\hline $\begin{array}{l}\text { Topsoil } \\
\text { S (mg/kg) }\end{array}$ & $\begin{array}{l}\mathrm{M} \\
\mathrm{R} \\
\mathrm{N} \\
\sigma\end{array}$ & $\begin{array}{l}711 \\
256-1843 \\
24 \\
306\end{array}$ & $\begin{array}{l}808 \\
324-2824 \\
28 \\
542\end{array}$ & $\begin{array}{l}666 \\
199-2559 \\
198 \\
354\end{array}$ & $\begin{array}{c}1014 \\
496-1808 \\
4 \\
611\end{array}$ & $\begin{array}{l}613 \\
565-661 \\
2 \\
68\end{array}$ & $\frac{1419}{-}$ \\
\hline $\begin{array}{r}\text { Subsoil S } \\
(\mathrm{mg} / \mathrm{kg})\end{array}$ & $\begin{array}{l}\mathrm{M} \\
\mathrm{R} \\
\mathrm{N} \\
\sigma\end{array}$ & $\begin{array}{l}405 \\
141-832 \\
23 \\
208\end{array}$ & $\begin{array}{l}377 \\
203-581 \\
22 \\
142\end{array}$ & $\begin{array}{l}351 \\
115-1070 \\
175 \\
182\end{array}$ & $\begin{array}{l}270 \\
173-370 \\
3 \\
98\end{array}$ & $\begin{array}{l}262 \\
196-329 \\
2 \\
94\end{array}$ & $\begin{array}{l}238 \\
-1 \\
-\end{array}$ \\
\hline
\end{tabular}

Table 2. Variation of herbage and soil S content with soil type

\begin{tabular}{|c|c|c|c|c|c|c|c|c|}
\hline & & Ranker & Brown earth & Gley & $\begin{array}{l}\text { Gleyed } \\
\text { ranker }\end{array}$ & $\begin{array}{c}\text { Gleyed } \\
\text { brown earth }\end{array}$ & $\begin{array}{c}\text { Alluvial } \\
\text { gley }\end{array}$ & Peaty gley \\
\hline $\begin{array}{l}\text { Herbage } \\
\text { S (\%) }\end{array}$ & $\begin{array}{l}\mathbf{M} \\
\mathbf{R} \\
\mathrm{N} \\
\sigma\end{array}$ & $\begin{array}{l}0 \cdot 315 \\
0 \cdot 211-0 \cdot 485 \\
33 \\
0 \cdot 069\end{array}$ & $\begin{array}{l}0 \cdot 336 \\
0 \cdot 207-0 \cdot 642 \\
104 \\
0 \cdot 078\end{array}$ & $\begin{array}{l}0 \cdot 263 \\
0 \cdot 218-0 \cdot 324 \\
3 \\
0 \cdot 055\end{array}$ & $\begin{array}{l}0 \cdot 260 \\
0 \cdot 208-0 \cdot 313 \\
3 \\
0 \cdot 053\end{array}$ & $\begin{array}{l}0 \cdot 253 \\
0 \cdot 180-0 \cdot 345 \\
8 \\
0 \cdot 057\end{array}$ & $\begin{array}{l}E \\
-\end{array}$ & $\begin{array}{l}0.297 \\
0 \cdot 251-0.379 \\
15 \\
0 \cdot 041\end{array}$ \\
\hline $\begin{array}{c}\text { Topsoil S } \\
\text { (mg/kg) }\end{array}$ & $\begin{array}{l}\mathrm{M} \\
\mathrm{R} \\
\mathrm{N} \\
\sigma\end{array}$ & $\begin{array}{l}654 \\
212-1843 \\
40 \\
260\end{array}$ & $\begin{array}{l}605 \\
256-1355 \\
136 \\
176\end{array}$ & $\begin{array}{c}1036 \\
413-2200 \\
5 \\
751\end{array}$ & $\begin{array}{l}617 \\
519-694 \\
3 \\
89\end{array}$ & $\begin{array}{l}727 \\
499-1808 \\
12 \\
351\end{array}$ & $\frac{1213}{1}$ & $\begin{array}{l}921 \\
255-2000 \\
13 \\
556\end{array}$ \\
\hline $\begin{array}{r}\text { Subsoil S } \\
(\mathrm{mg} / \mathrm{kg})\end{array}$ & $\begin{array}{l}\mathrm{M} \\
\mathrm{R} \\
\mathrm{N} \\
\sigma\end{array}$ & $\begin{array}{l}389 \\
116-864 \\
24 \\
169\end{array}$ & $\begin{array}{l}323 \\
115-696 \\
127 \\
125\end{array}$ & $\begin{array}{l}553 \\
130-1070 \\
5 \\
438\end{array}$ & ${ }_{1}^{251}-$ & $\begin{array}{l}453 \\
222-986 \\
12 \\
236\end{array}$ & $\frac{1344}{1}$ & $\begin{array}{l}367 \\
173-581 \\
13 \\
123\end{array}$ \\
\hline
\end{tabular}

$\mathrm{M}$, Mean; $\mathrm{R}$, range; $\mathrm{N}$, number of samples; $\sigma$, standard deviation.

of $\mathbf{S}$ between soils developed on different parent materials (Table 1). The subsoil $\mathrm{S}$ content might be expected to reflect the distribution in the underlying parent material of the residual soils, but although the subsoils derived from igneous rocks (apart from the Precambrian keratophyre) have slightly higher mean $S$ contents than the soils developed on sedimentary parent materials, the difference is small and the ranges and standard deviations of the various groups are large.

When relating $S$ content to soil type, the gleyed topsoils have a higher mean $S$ content than the more freely drained topsoils, except for the gleyed rankers (Table 2). Soil S contents appear to increase as soil drainage becomes poorer; this is particularly noticeable in the topsoils (Fig. 3, Table 3).

The concentration of $S$ in plants in this area ranged from 0.180 to $0.560 \%$, with a mean of $0.310 \%$. No clear relationship with soil $\mathrm{S}$ content can be seen, and herbage with a low concentration of $\mathrm{S}$ often occurs on a soil containing much $\mathrm{S}$. Table 2 shows that gleyed soils support herbage containing less $\mathrm{S}$ than that growing on ungleyed soils. The relationship between soil drainage and the $S$ content of the herbage is the inverse of the soil drainage, soil $\mathrm{S}$ relationship (Fig. 3, Table 3).

The sulphur contents of herbage harvested from March to August at the same locations did not show a systematic seasonal variation (Table 4). Different rates of $\mathbf{S}$ uptake by grass and clover were apparent when both were harvested at the same time at the same site; most of the clover samples contained slightly less $\mathbf{S}$ than the grass from the same sites.

In the areas sampled throughout the growing season, grass from the poorly drained localities contained less $\mathrm{S}$ than grass from the better drained sites.

To test the reproducibility of herbage sampling in the field, a transect was made with samples taken $1,2,3$ and $4 \mathrm{~m}$ each side of the correct sample position. The $\mathrm{S}$ and Ti values are plotted in Fig. 4. The greatest values of $S$ relate to samples with large $\mathrm{Ti}$ contents and contamination by soil gives rise to $\mathrm{S}$ values $25 \%$ greater than the mean of the uncontaminated samples. However, there are 
Table 3. Variation of soil and herbage $S$ content with soil drainage

Well drained

Drainage class

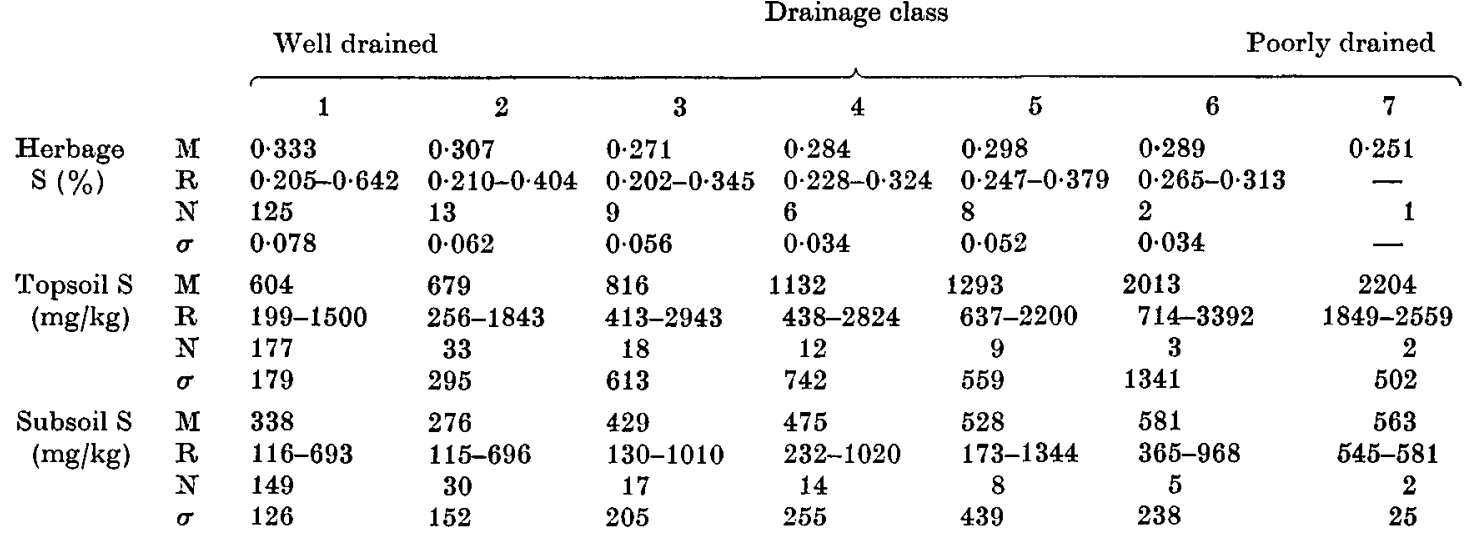

$\mathrm{M}$, Mean; $\mathbf{R}$, range; $N$, number of samples; $\sigma$, standard deviation.

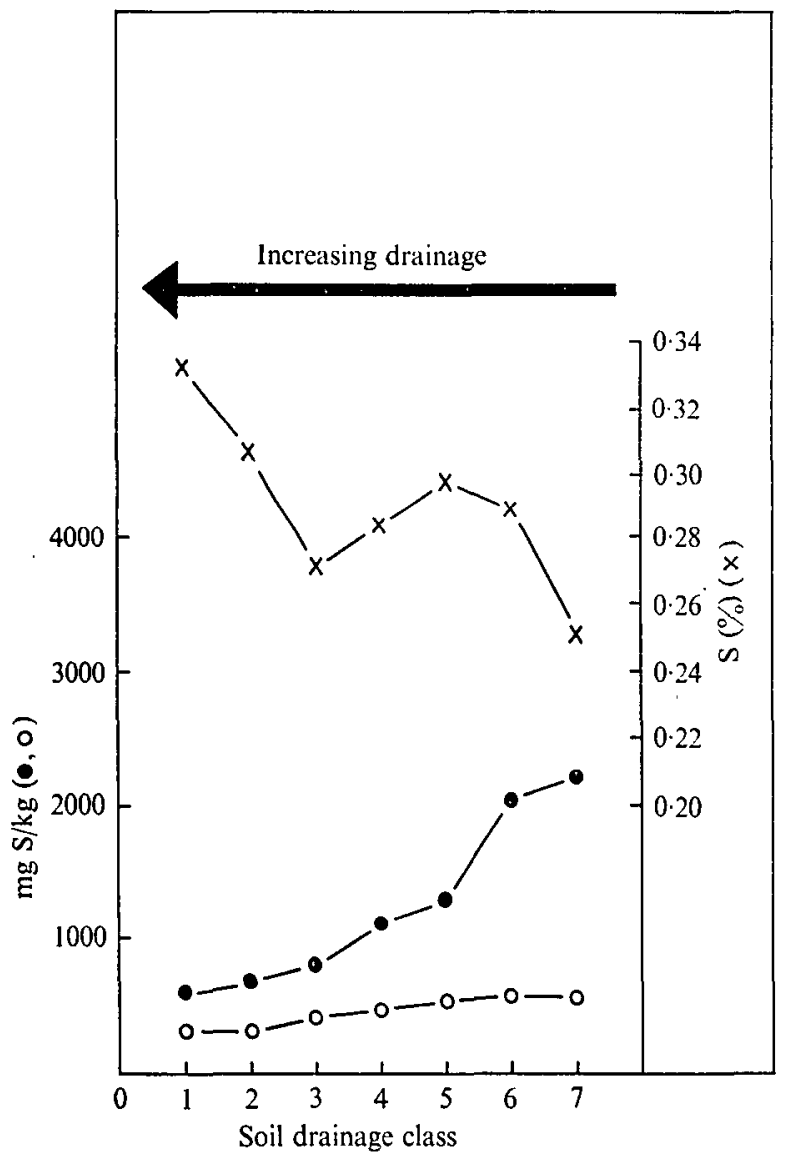

Fig. 3. The relationship between soil drainage and mean sulphur concentration in soils and herbage. $x-x$, Herbage $\mathrm{S}(\%)$; - 
Table 4. Seasonal variation in $S$ uptake by grass

\begin{tabular}{|c|c|c|c|c|c|c|c|}
\hline \multirow{2}{*}{$\begin{array}{l}\text { Grid reference } \\
\text { of sample }\end{array}$} & \multicolumn{5}{|c|}{$\mathrm{S}$ in monthly samples $(\%)$} & \multirow{2}{*}{$\begin{array}{l}\text { Mean } \\
\% \mathrm{~S}\end{array}$} & \multirow{2}{*}{$\begin{array}{l}\text { Drainage } \\
\text { class of soil }\end{array}$} \\
\hline & March & May & June & July & August & & \\
\hline SM 860240 & 0.385 & 0.315 & $0 \cdot 310$ & 0.500 & 0.435 & 0.387 & 1 \\
\hline 870250 & $0 \cdot 320$ & 0.440 & 0.337 & $0.397 *$ & 0.406 & 0.380 & 1 \\
\hline 870270 & $0.516^{*}$ & $0.250^{*}$ & $0 \cdot 277$ & $0.224^{*}$ & 0.314 & $0 \cdot 316$ & 1 \\
\hline 880240 & $0 \cdot 280^{*}$ & $0.298^{*}$ & 0.366 & 0.306 & 0.341 & 0.318 & 1 \\
\hline 880260 & 0.418 & 0.337 & $0 \cdot 329$ & $0 \cdot 386$ & 0.395 & 0.373 & 1 \\
\hline 880280 & $0.400^{*}$ & 0.274 & $0 \cdot 388$ & 0.539 & 0.517 & 0.424 & 1 \\
\hline 950350 & 0.484 & 0.332 & $0.232 *$ & 0.531 & $0 \cdot 431^{*}$ & 0.402 & 1 \\
\hline 950370 & 0.359 & 0.377 & $0 \cdot 281$ & 0.288 & 0.396 & 0.340 & 1 \\
\hline 960340 & 0.391 & $0 \cdot 341$ & $0 \cdot 357$ & 0.476 & 0.376 & 0.388 & 1 \\
\hline 960360 & $0 \cdot 389$ & 0.422 & 0.217 & 0.510 & $0 \cdot 499$ & 0.407 & 1 \\
\hline 970370 & $0 \cdot 360$ & 0.339 & $0 \cdot 336$ & 0.264 & n.s. & 0.325 & 1 \\
\hline 980340 & $0.757 *$ & $0.450^{*}$ & $0 \cdot 447$ & 0.418 & 0.339 & 0.482 & 1 \\
\hline 980360 & 0.341 & $0 \cdot 309$ & $0 \cdot 414^{*}$ & 0.395 & 0.471 & 0.386 & 1 \\
\hline 980380 & $0 \cdot 321$ & 0.316 & 0.289 & 0.305 & 0.275 & 0.301 & 1 \\
\hline 990350 & $0 \cdot 442$ & $0 \cdot 449$ & $0.439^{*}$ & $0.510^{*}$ & $0.507 *$ & 0.469 & 1 \\
\hline 990370 & $0.310^{*}$ & $0.328^{*}$ & $0 \cdot 336^{*}$ & $0.346 *$ & 0.327 & 0.329 & 1 \\
\hline 890250 & $0.240^{*}$ & 0.350 & 0.345 & 0.218 & 0.343 & 0.299 & 2 \\
\hline 860280 & $0 \cdot 360$ & $0 \cdot 270$ & $0 \cdot 228$ & 0.242 & 0.220 & 0.264 & 4 \\
\hline 860260 & $0 \cdot 195^{*}$ & $0.251^{*}$ & $0 \cdot 248$ & 0.300 & $0.398^{*}$ & 0.278 & 5 \\
\hline \multirow[t]{2}{*}{870250} & 0.389 & 0.257 & 0.247 & $0 \cdot 250$ & n.s. & 0.285 & 5 \\
\hline & \multicolumn{5}{|c|}{$\begin{array}{l}\text { n.s., Not sampled. } \\
\text { * Contaminated sample, high Ti content. }\end{array}$} & & \\
\hline
\end{tabular}

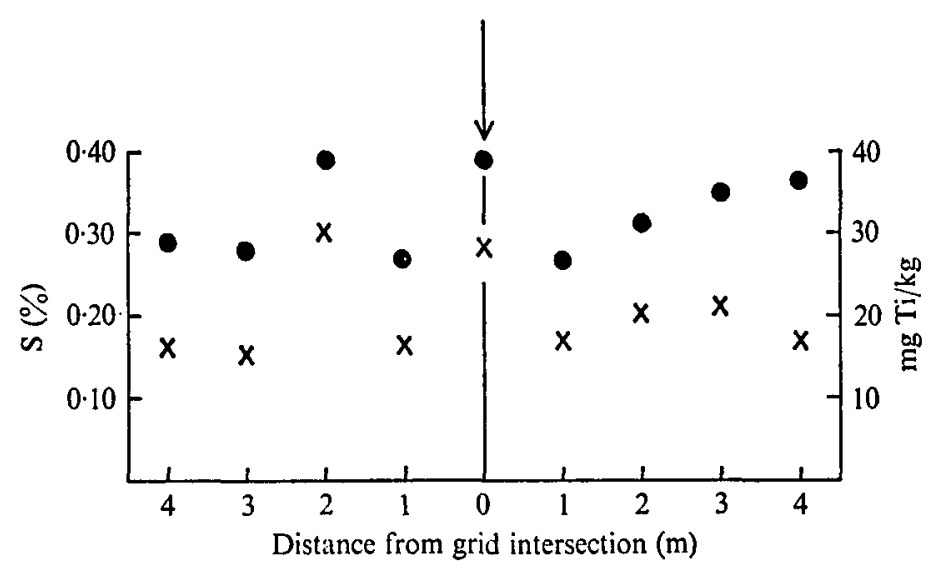

Fig. 4. Variation of $\mathrm{S}$ and $\mathrm{Ti}$ in herbage near a sample point. $\bullet, \mathrm{S} \% ; \times, \mathrm{Ti} \mathrm{mg} / \mathrm{kg}$ (semi-quantitative results, not corrected for background); $\downarrow$, sample point at grid intersection.

$\pm 10 \%$ variations in the $S$ contents of the samples of similar Ti content, which illustrates the magnitude of sampling and individual variation combined with experimental error which can be expected over $9 \mathrm{~m}$. Examination of the $\mathrm{S}$ contents of herbage samples with high Ti over the whole of the surveyed area gave no clear indication of the amount of contamination by soil $\mathrm{S}$ which might be expected. Many soils contain less $\mathrm{S}$ than the related herbage so contamination could lead to decreased $\mathbf{S}$ values in some samples.

\section{DISCUSSION AND CONCLUSIONS}

There are many variable factors and, no doubt, unknown factors in a survey of this type. The results therefore suggest possible explanations and indicate areas in which more research should be done under 


\section{Sulphur in soils and herbage of Pembrokeshire}

more controlled conditions. Some difficulties encountered in this type of study are (1) the unknown effects of different fertilizer practice on various farms, (2) the necessity of sampling existing herbage which may give rise to variations in $\mathbf{S}$ uptake due to the varying requirements of different species rather than environmental differences, (3) tho sampling of uncontaminated herbage, and (4) reproducibly sampling at different times from the same site.

By specifically sampling pasture plants, mainly grass and clover, difficulty (2) was partly overcome, although clover was shown to take up slightly less $\mathrm{S}$ than grass, and variations within different species of grass were not investigated. As an indicator of contamination of herbage by soil, Ti was determined (difficulty (3)), and to estimate difficulty (4) the sampling plus analytical error in sampling herbage within $\pm 4 \mathrm{~m}$ of a specific sampling point was determinod as $\pm 10 \%$.

In spite of the large errors to be expected in the results of this type of survey, the following points became evident:

(1) Large amounts of $\mathrm{S}$ occur in highly organic soils.

(2) Soil $\mathrm{S}$ increased as soil drainage became poorer.

(3) The relationship between soil $\mathrm{S}$ and $\mathrm{S}$ taken up by pasture plants is not straightforward. It is likely that the percentage of $S$ available for plant uptake is lower in organic soils than inorganic soils.

(4) The $S$ content of herbage decreased as soil drainage became poorer, thus showing an inverse relationship to the behaviour of soil S.

(5) There was no clear seasonal variation in herbage $S$ content.

(6) The results of the survey suggest that parts of Pembrokeshire might be $S$ deficient with regard to pasture plants.

The overall pattern, in this area, of soils with large concentrations of organic matter containing large amounts of $S$ is in agreement with results published from other areas. For example, Tabatai \& Bremner (1972) found that the total $S$ in the soils of Iowa was significantly correlated with both organic carbon and total nitrogen; soil $\mathrm{S}$ also decreased markedly down the profile. Freney (1961) and Freney \& Simpson (1973) fractionated S from Australian surface soils and found that only $6 \%$ of the $\mathrm{S}$ was present as adsorbed and soluble sulphate, and that only $1 \%$ was in inorganic forms of a lower oxidation state; the remainder was presumed to be organic. Of the total soil $\mathrm{S}$, only $59 \%$ was reducible using a mixture of hydriodic, formic and hypophosphorous acids (after Johnson \& Nishita, 1952). A strong relationship was found between adsorbed sulphate and the amount of $\mathrm{S}$ taken up by plants during pot trials but the organic part of the reducible fraction (approximately $52 \%$ of soil $\mathrm{S}$ ) did not appear to be utilized by plants in pot experiments (Freney, 1961; Spencer \& Freney, 1960).

Freney's results show the importance of organic matter in the sulphur cycle, and showed that in his Australian soils there was a strong correlation between the reducible fraction of soil $S$ and organio $\mathrm{C}$ and total $\mathrm{N}$. As very little of the reducible $\mathrm{S}$ is taken up by plants, this could explain the results in Pembrokeshire soils, where large concentrations of $S$ in the soil were not reflected by the amounts of $S$ in the herbage.

In this survey, a clearer relationship was found between soil drainage and both soil and herbage $S$ contents than between the $S$ and organic-matter contents. Whereas $S$ in the topsoil increased as the soils became more poorly drained, $\mathrm{S}$ in the herbage decreased. Possibly, soil S becomes more associated with the fraction of organic compounds unavailable to plants as soil drainage deteriorates. However, this pattern may simply be caused by the different $S$ requirements and uptake of grasses that favour growth on poorly drained and well drained sites. The accumulation of $S$ in poorly drained soils may be due to the less severe leaching to which these soils are subjected.

The concentration of $S$ in herbage was found to be very much greater than the concentration in the soil, and no clear relationship was found between the two. Plants are known to obtain $\mathrm{S}$ from the atmosphere (Cowling \& Jones, 1970) and this will tend to obscure any relationship between plant and soil S contents.

The $S$ contents of the Pembrolkeshire herbage ranged from 0.180 to $0.560 \%$, with a mean of $0.310 \%$. Other workers have found that if other factors, especially $\mathrm{N}$, are not limiting, maximum dry-matter production of grass is achieved if the $S$ content is between 0.25 and $0.30 \%$ (McNaught \& Christoffels, 1961), or is about $0.32 \%$ (Walker \& Adams, 1958; Walker, Adams \& Orchiston, 1956); smaller critical concentrations of $S$ apply if the plant $\mathrm{N}$ level is also smaller. Using the smallest value quoted above as the criterion with which to assess $\mathrm{S}$ deficiency, although not knowing the $\mathrm{N}$ content of the plant, it is possible that up to $14 \%$ of the Pembrokeshire herbage may be $\mathrm{S}$ deficient.

The author is grateful to C. C. Rudeforth and R. I. Bradley for supplying soil samples and field data, Mrs B. J. Devonshire and K. Perrins for analytical data and to G. Brown for discussion on the agricultural importance of sulphur. 


\section{REFERENCES}

BALL, D. F. (1964). Loss on ignition as an estimate of organic matter and organic carbon in non-calareous soils. Journal of Soil Science 15, 84-92.

Bolton, J. \& Benzian, B. (1970). Sulphur as a nutrient for Sitka spruce (Picae sitchensis) seedlings and radish (Raphanus sativus) grown on a sandy podzol in England. Journal of Agricultural Science, Cambridge 74, 501-4.

Bolton, J., Brown, G., Pruden, G. \& Williams, C. (1973). A comparison of X-ray fluorescence spectrometry and chemical methods for determining sulphur in plant material. Journal of the Science of Food and Agriculture 24, 557-63.

Brows, G. \& Kanaris-Sotrriou, R. (1969). The determination of sulphur in soils by $\mathrm{X}$-ray fluorescence analysis. Analyst 94, 782-6.

Cowming, D. W. \& Jones, L. H. P. (1970). A deficiency in soil sulphur supplies for perennial ryegrass in England. Soil Science 110, 346-54.

Freney, J. R. (1961). Some observations on the nature of organic sulphur compounds in soil. Australian Journal of Agricultural Research 12, 424-32.

Freney, J. R. \& Simpson, J. R. (1973). Transformations of labelled nitrogen and sulphur in soil. Procedures of Symposium on Hydrogeochemistry and Biogeochemistry, I/II, Tokyo, 1970 (ed. Earl Ingerson), pp. 409-21.

Johnson, C. M. \& Nishita, H. (1952). Microestimation of sulphur in plant materials, soils and irrigation waters. Analytical Chemistry 24, 736-42.
McNaught, K. J. \& Christoffels, P. J. E. (1961). Effect of sulphur deficiency on sulphur and nitrogen levels in pastures and lucerne. New Zealand Joumal of Agricultural Research 4, 177-96.

Rudeforth, C. C. \& Bradley, R. I. (1972). Soils, Land Classification and Land use of West and Central Pembrokeshire, 29 pp. Special Survey no. 6. Soil Survey of England and Wales, Harpenden.

SPENCER, K. \& FRENEY, J. R. (1960). A comparison of several procedures for estimating the sulphur status of soils. Australian Journal of Agricultural Research 11, 948-59.

SulPhuR Institute (1962). Sulphur, The Essential Plant Food Element, 29 pp. Sulphur Institute, Washington.

Tabatai, M. A. \& Bremener, J. M. (1972). Forms of sulphur and carbon, nitrogen and sulphur relationships, in Iowa soils. Soil Science 114, 380-6.

Walker, T. W. \& Anams, A. F. R. (1958). Competition for sulphur in a grass-clover association. Plant and Soil 9, 353-66.

Walker, T. W., Adams, A. F. R. \& Orchiston, H. D. (1956). The effects of levels of calcium sulphate on the yield and composition of a grass and clover pasture. Plant and Soil 7, 290-300.

WIILIAMs, C. (1974). The accumulation of lead in soils and herbage at Rothamsted Experimental Station. Journal of Agricultural Science, Cambridge 82, 189-92. 